\author{
Magdalena Jankowska \\ Uniwersytet Mikołaja Kopernika w Toruniu \\ mjankowska@umk.pl
}

\title{
Pomoc bagatelna jako szczególna forma wsparcia publicznego małych i średnich przedsiębiorców
}

\author{
De minimis Aid as a Special Form of Public Support for Small \\ and Medium Entrepreneurs
}

\section{STRESZCZENIE}

Pomoc de minimis - jako pomoc bagatelna, cechująca się niewielkimi rozmiarami i niezdolnością do zakłócenia konkurencji na rynku wewnętrznym - może być przyznawana przedsiębiorcom bez konieczności zgłaszania Komisji Europejskiej. Problematyka związana z jej funkcjonowaniem jest uregulowana w różnorodnych aktach prawa krajowego i międzynarodowego. Podstawowym źródłem prawa dotyczącym wsparcia bagatelnego jest rozporządzenie Komisji (UE) nr 1407/2013. Na gruncie regulacji polskich decydujące znaczenie przypisuje się ustawie z dnia 30 kwietnia $2004 \mathrm{r}$. o postępowaniu w sprawach dotyczących pomocy publicznej i rozporządzeniom Rady Ministrów uzupełniającym i rozwijającym postanowienia ustawowe. W niniejszym artykule autorka poddaje analizie obecnie obowiązujące przepisy w przedmiocie pomocy bagatelnej oraz wskazuje na zasady udzielania pomocy de minimis, przejrzystą procedurę jej przyznawania i proces jej monitorowania. W kontekście swoich rozważań i przytaczanych danych liczbowych z lat 2012-2016 wskazuje na rosnącą rolę największych beneficjentów pomocy bagatelnej, czyli mikro, małych i średnich przedsiębiorców, będących siłą napędową rozwoju gospodarczego w Polsce.

Słowa kluczowe: pomoc publiczna; pomoc bagatelna; pomoc de minimis; mikroprzedsiębiorca; mały przedsiębiorca; średni przedsiębiorca; MŚP 


\section{POMOC PUBLICZNA A POMOC BAGATELNA}

Instytucja pomocy publicznej dla przedsiębiorców funkcjonuje w polskim porządku prawnym od momentu ustanowienia Układu Europejskiego z 1991 r. ${ }^{1}$, który nałożył na Polskę obowiązek dostosowania prawa krajowego do prawa unijnego m.in. przez wprowadzenie reguł dopuszczalności pomocy publicznej oraz odpowiednich procedur z zakresu nadzorowania wskazanej pomocy. Pomoc publiczna polega na podejmowaniu działań przez organy władzy państwowej lub realizowaniu przedsięwzięć finansowanych z zasobów państwowych, wspierających ekonomicznie działalność określonych przedsiębiorstw, sektorów gospodarki, regionów lub wytwarzanie określonych produktów ${ }^{2}$. Takie selektywne przysporzenie finansowych korzyści przedsiębiorcy powoduje powstanie obciążenia finansowego po stronie finansów publicznych ${ }^{3}$.

Problematyka pomocy publicznej została przedstawiona w art. 107-109 Traktatu o funkcjonowaniu Unii Europejskiej ${ }^{4}$. Zgodnie z art. 107 ust. 1 TFUE:

[...] z zastrzeżeniem innych postanowień przewidzianych w niniejszym Traktacie, wszelka pomoc przyznawana przez Państwo Członkowskie lub przy użyciu zasobów państwowych w jakiejkolwiek formie, która zakłóca lub grozi zakłóceniem konkurencji poprzez sprzyjanie niektórym przedsiębiorstwom lub produkcji niektórych towarów, jest niezgodna ze wspólnym rynkiem w zakresie, w jakim wpływa na wymianę handlową między Państwami Członkowskimi.

Przepis ten nie zawiera dokładnej definicji pomocy publicznej, lecz wylicza przesłanki, których łączne spełnienie powoduje, iż dane wsparcie zostaje zakwalifikowane do kategorii pomocy publicznej, a tym samym - uznane za zakazane ${ }^{5}$. Pierwszą z przesłanek jest pochodzenie środka finansowego od państwa lub z zaso-

1 Układ Europejski ustanawiający stowarzyszenie między Rzecząpospolitą Polską, z jednej strony, a Wspólnotami Europejskimi i ich państwami członkowskimi, z drugiej strony, sporządzony w Brukseli dnia 16 grudnia 1991 r. (Dz.U. z 1994 r., nr 11, poz. 38).

2 A. Fornalczyk, Rodzaje, formy i instrumenty pomocy publicznej w Unii Europejskiej $i$ w Polsce, [w:] Pomoc publiczna dla przedsiębiorstw w Unii Europejskiej i w Polsce, red. A. Fornalczyk, Warszawa 1998, s. 14.

3 J. Choroszczak, M. Mikulec, Pomoc publiczna a rozwój firmy. Szanse i zagrożenia, Warszawa 2012, s. 11.

4 Traktat o Unii Europejskiej i Traktat o funkcjonowaniu Unii Europejskiej, wersja skonsolidowana (Dz.Urz. UE C 202, 07.06.2016), dalej jako: TFUE.

5 Brak traktatowej definicji umożliwia Komisji Europejskiej i Trybunałowi Sprawiedliwości Unii Europejskiej dokonywanie własnej interpretacji tego pojęcia w możliwie szerokim zakresie, przy czym interpretacja ta powinna być dokonywana wyłącznie w kontekście przepisów unijnego porządku prawnego. Zob. A. Borkowski, Pomoc publiczna jako funkcja państwa wobec społecznej gospodarki rynkowej, „Przegląd Prawa i Administracji” 2015, nr 103, s. 17-18. 
bów państwowych ${ }^{6}$. Chodzi tu o pomoc udzielaną przez organy władzy publicznej, czyli wszelkie podmioty wykonujące władcze funkcje państwa na szczeblu centralnym, regionalnym i lokalnym ${ }^{7}$. Mowa tu także o innych podmiotach publicznych lub prywatnych, które są kontrolowane przez państwo członkowskie lub którym powierzono zarządzanie środkami publicznymi ${ }^{8}$. Druga przesłanka wskazuje, że wsparcie selektywnie faworyzuje niektóre przedsiębiorstwa lub branże. Z selektywnością mamy do czynienia, gdy przez przekazanie pomocy uprzywilejowany jest określony przedsiębiorca, przedsiębiorcy, gałęzie produkcji, usługi lub region, na którym następuje koncentracja środków publicznych ${ }^{9}$. Przy określeniu, czy dane działanie państwa stanowi pomoc publiczną, decydującego znaczenia nie ma przyczyna czy cel podjęcia określonego działania, lecz jego skutek w postaci negatywnego wpływu na handel między państwami członkowskimi, będący wynikiem uprzywilejowania określonych przedsiębiorców lub gałęzi produkcji ${ }^{10}$. W myśl trzeciej przesłanki środek pomocowy zakłóca lub grozi zakłóceniem konkurencji. Oznacza to, że przy ocenie stanu danego rynku istotne jest rozstrzyganie kwestii potencjalnego bądź realnego naruszenia konkurencji na tym rynku przez udzielenie danemu beneficjentowi wnioskowanej pomocy ${ }^{11}$. Czwarta przesłanka jest związana z wywieraniem wpływu przez pomoc publiczną na wymianę handlową między państwami członkowskimi. Do wpływu na handel unijny ${ }^{12}$ dochodzi, gdy beneficjent pomocy konkuruje swoją działalnością z podmiotami z innych państw członkowskich Unii Europejskiej, przy czym negatywny wpływ pomocy na wymianę handlową polega na udzielaniu przez kraj członkowski pomocy przedsiębiorstwu, którego przedsięwzięcia pozostają w konkurencji z towarami lub usługami importowanymi z innego kraju członkowskiego, nawet jeśli dane przedsięwzięcie nie wiąże się z eksportem towarów lub usług ${ }^{13}$.

6 Wyrok TSUE z dnia 21 marca 1991 r. w sprawie C-303/88 Italian Republic v. Commission, Zb. Orz. 1991, s. I-1433.

7 A. Jankowska, M. Marek, Dopuszczalność pomocy publicznej. Uregulowania wspólne i krajowe, Warszawa 2009, s. 13.

8 A. Jankowska, Pomoc publiczna dla przedsiębiorców w świetle uregulowań wspólnotowych. Zasady i ograniczenia udzielania, Warszawa 2005, s. 7.

9 J.W. Wiktor, Rynek Unii Europejskiej. Koncepcja i zasady funkcjonowania, Kraków 2005, s. 111.

10 Wyrok TSUE z dnia 26 września 1996 r. w sprawie C-241/94 France v. Commission, Zb. Orz. 1996, s. I-4551.

11 P. Marquardt, Pomoc publiczna dla matych i średnich przedsiębiorców, Warszawa 2007, s. 53.

12 Pojęcie handlu należy rozumieć szeroko - jako wszelkie aspekty międzynarodowej wymiany gospodarczej, w tym przepływy kapitału. Zob. Pomoc publiczna w Programach Operacyjnych 2007-2013. Poradnik dla administracji publicznej wraz z komentarzami do rozporzadzeń Ministra Rozwoju Regionalnego, Ministerstwo Rozwoju Regionalnego, marzec 2008, s. 18.

13 A. Jankowska, op. cit., s. 8. 
Spełnienie wskazanych przesłanek łącznie zasadniczo przesądza o uznaniu pomocy za niezgodną z rynkiem wewnętrznym i w związku z tym za niedozwoloną ${ }^{14}$. W obecnie obowiązującym porządku prawnym istnieją jednak dopuszczalne formy wsparcia publicznego, które realizują szeroko rozumiane cele nie tylko państwa udzielającego pomocy, lecz także cele samej Unii Europejskiej w zakresie działania na rzecz rozwoju, którego podstawę stanowią: zrównoważony wzrost gospodarczy, dążenie do pełnego zatrudnienia i postępu naukowo-technicznego, wspieranie spójności gospodarczej w Unii Europejskiej i solidarności pomiędzy państwami członkowskimi ${ }^{15}$. Do takich postaci zalicza się: wsparcie publiczne zgodne z zasadami wspólnego rynku z mocy prawa, wsparcie publiczne uznane za zgodne z zasadami wspólnego rynku na podstawie decyzji Komisji Europejskiej, a także wsparcie publiczne, które nie spełnia kumulatywnie warunków zaprezentowanych w art. 107 ust. 1 TFUE. Do tego ostatniego należy m.in. pomoc de minimis (pomoc bagatelna), która nie wyczerpuje przesłanki wpływu na wspólny rynek ${ }^{16}$ i ze względu na swoją małą wartość nie oddziałuje na wymianę handlową w wymiarze unijnym. $Z$ formalnego punktu widzenia pomoc ta nie stanowi pomocy publicznej i nie podlega zakazowi wynikającemu $\mathrm{z}$ analizowanego przepisu Traktatu.

\section{POMOC BAGATELNA - PODSTAWOWE ZAŁOŻENIA}

Kwestie związane z funkcjonowaniem pomocy bagatelnej i regułami jej przyznawania są uregulowane $\mathrm{w}$ drodze różnorodnych aktów prawa krajowego i ponadkrajowego. Podstawowym źródłem prawa dotyczącym problematyki wsparcia bagatelnego jest rozporządzenie Komisji (UE) nr 1407/2013 z dnia 18 grudnia 2013 r. w sprawie stosowania art. 107 i 108 Traktatu o funkcjonowaniu Unii Europejskiej do pomocy de minimis ${ }^{17}$. Na gruncie regulacji polskich decydujące znaczenie przypisuje się ustawie z dnia 30 kwietnia 2004 r. o postępowaniu w sprawach dotyczących pomocy publicznej ${ }^{18}$. Jej postanowienia uzupełniają i rozwijają:

${ }^{14}$ Wyrok TSUE z dnia 22 marca 1977 r. w sprawie C-78/76 Steinike \& Weinlig v. Germany, Zb. Orz. 1977, s. 595.

15 A. Borkowski, op. cit., s. 19.

${ }^{16}$ Jeżeli chodzi o przesłanki dotyczące wywierania przez korzyść gospodarczą wpływu na wymianę handlową między państwami członkowskimi oraz zakłócenia konkurencji, do których korzyść ta może prowadzić, należy przypomnieć, że w celu zakwalifikowania środka krajowego jako pomocy państwa nie jest konieczne stwierdzenie faktycznego wpływu danej pomocy na wymianę handlową między państwami członkowskimi i rzeczywistego zakłócenia konkurencji, lecz jedynie zbadanie, czy owa pomoc może mieć wpływ na tę wymianę handlową i zakłócać konkurencję. Zob. wyrok TSUE z dnia 21 grudnia 2016 r. w sprawie C-76/15 Vervloet $i$ in., pkt 102 (Dz.Urz. UE C 53, 20.02.2017).

${ }^{17}$ Dz.Urz. UE L 352, 24.12.2013, s. 1, dalej jako: rozporządzenie Komisji nr 1407/2013.

18 T.j. Dz.U. z 2018 r., poz. 362. 
- rozporządzenie Rady Ministrów z dnia 29 marca 2010 r. w sprawie zakresu informacji przedstawianych przez podmiot ubiegający się o pomoc de minimis $^{19}$,

- rozporządzenie Rady Ministrów z dnia 20 marca 2007 r. w sprawie zaświadczeń o pomocy de minimis i pomocy de minimis $\mathrm{w}$ rolnictwie lub rybołówstwie ${ }^{20}$.

Pomoc de minimis cechuje się niewielkimi rozmiarami i w myśl maksymy de minimis not curat lex (prawo nie troszczy się o drobiazgi) jest niezdolna do zakłócenia konkurencji na rynku wewnętrznym ${ }^{21}$. $\mathrm{Z}$ tego też powodu może być przyznawana przedsiębiorcom bez potrzeby zgłaszania Komisji Europejskiej ${ }^{22}$. Pomoc de minimis nie musi być notyfikowana zarówno gdy jest udzielana jako pomoc indywidualna, jak i gdy formą jej przyznania jest program pomocowy ${ }^{23}$. W prawie europejskim zasada de minimis pojawiła się w 1992 r. ${ }^{24}$ Głównym celem jej wprowadzenia i później praktykowania było ograniczenie ilości spraw, którymi dotychczas zajmowała się Komisja Europejska, tak aby mogła się ona skoncentrować tylko na sprawach istotnych z punktu widzenia naruszenia konkurencji w Unii Europejskiej ${ }^{25}$.

Beneficjentem omawianej pomocy jest przedsiębiorca. Warto podkreślić, że pojęcie przedsiębiorcy odnosi się do wszystkich podmiotów prowadzących działalność gospodarczą, bez względu na formę prawną i sposób finansowania, a także niezależnie od tego, czy przepisy krajowe przyznają danemu podmiotowi status przedsiębiorcy. Stwierdzenie takie wynika z treści art. 1 załącznika do zalecenia Komisji Europejskiej 2003/361/WE ${ }^{26}$, który - mimo że nie wyprowadza definicji przedsiębiorcy - odnosi się do pojęcia przedsiębiorstwa. Zgodnie ze wskazanym przepisem:

[...] za przedsiębiorstwo uznaje się każdy podmiot prowadzący działalność gospodarczą, niezależnie od jego formy prawnej. Obejmuje to w szczególności osoby prowadzące działalność na własny rachunek oraz firmy rodzinne prowadzące działalność rzemieślniczą lub inne rodzaje działalności, oraz spółki cywilne lub stowarzyszenia regularnie prowadzące działalność gospodarczą.

\footnotetext{
19 Dz.U. z 2010 r., nr 53, poz. 311.

20 T.j. Dz.U. z 2018 r., poz. 350.

${ }^{21}$ J. Szóstakowska, Pomoc publiczna, http://uniaeuropejska.org/pomoc-publiczna [dostęp: 08.03.2018].

${ }^{22}$ A. Jankowska, op. cit., s. 73.

23 A. Jankowska, M. Marek, op. cit., s. 115.

${ }^{24}$ Wspólnotowe wytyczne w sprawie pomocy dla małych i średnich przedsiębiorców (Dz.Urz. UE C 213, 19.08.1992, s. 2).

25 P. Pełka, M. Stasiak, Pomoc publiczna dla przedsiębiorców w Unii Europejskiej, Warszawa 2002, s. 37-38.

${ }^{26}$ Zalecenie Komisji Europejskiej 2003/361/WE z dnia 6 maja 2003 r. dotyczące definicji przedsiębiorstw mikro, małych i średnich (Dz.Urz. UE L 124, 20.05.2003).
} 
W związku z powyższym odbiorcami pomocy publicznej mogą być nie tylko przedsiębiorcy w rozumieniu przepisów ustawy z dnia 6 marca 2018 r. - Prawo przedsiębiorców ${ }^{27}$, ale także przykładowo zakłady budżetowe, stowarzyszenia, fundacje, o ile prowadzą działalność gospodarczą. W przedmiocie klasyfikacji przedsiębiorstw wypowiada się art. 2 załącznika do zalecenia Komisji Europejskiej 2003/361/WE, w myśl którego „na kategorię przedsiębiorstw mikro, małych i średnich (MŚP) składają się przedsiębiorstwa, które zatrudniają mniej niż 250 osób i których obroty roczne nie przekraczają $50 \mathrm{mln}$ euro, i/lub których roczna suma bilansowa nie przekracza $43 \mathrm{mln}$ euro". Za małe przedsiębiorstwo uważa się przedsiębiorstwo zatrudniające mniej niż 50 osób, którego obroty roczne i/ lub roczna suma bilansowa nie przekracza 10 mln euro. Natomiast przez przedsiębiorstwo mikro, które współcześnie stanowi najczęstszą formę rozpoczynania działalności gospodarczej i wejścia na rynek ${ }^{28}$, rozumie się przedsiębiorstwo zatrudniające mniej niż 10 osób, którego obroty roczne i/lub roczna suma bilansowa nie przekracza $2 \mathrm{mln}$ euro.

Mikro, małe i średnie przedsiębiorstwa odgrywają kluczową rolę we współczesnej gospodarce europejskiej. Stanowią jej siłę napędową i są jednocześnie kwintesencją przedsiębiorczości. Dzięki innowacyjności i elastyczności podejmowanych działalności znacząco wpływają na dynamikę rozwoju gospodarczego. Ponadto pozwalają zmniejszać bezrobocie, uzupełniają rynek w zakresie produkcji towarów i świadczenia usług, a także ożywiają gospodarkę lokalną ${ }^{29}$. Pomimo tego właśnie te przedsiębiorstwa najczęściej zmagają się z niedoskonałościami rynku i mają trudności z uzyskaniem kapitału, zwłaszcza w fazie uruchamiania działalności gospodarczej. Z tego powodu w obecnym porządku prawnym wsparcie MŚP stanowi główny priorytet polityki ekonomicznej państwa w przedmiocie wzrostu gospodarczego i tworzenia miejsc pracy ${ }^{30}$. Jedną $\mathrm{z}$ form takiego wsparcia jest pomoc de minimis, której poświęcono niniejsze opracowanie.

\section{ZASADY PRZYZNAWANIA POMOCY BAGATELNEJ}

Pomoc de minimis najczęściej przybiera formę dotacji, ulg podatkowych, pożyczek, kredytów preferencyjnych, poręczeń, gwarancji. Reguły przyznawania pomocy bagatelnej zakładają, iż łączna jej wartość dla jednego beneficjenta nie

${ }^{27}$ Dz.U. z 2018 r., poz. 646.

${ }^{28}$ F. Misiąg, Charakterystyka sektora MSP, [w:] Pomoc publiczna dla matych i średnich przedsiębiorstw. Mity i rzeczywistość, red. F. Misiąg, Warszawa 2005, s. 20.

${ }_{29}$ M. Strużycki, Specyfika działalności rynkowej małych i średnich przedsiębiorstw, [w:] Zarządzanie małym i średnim przedsiębiorstwem, red. M. Strużycki, Warszawa 2002, s. 20.

${ }^{30}$ Nowa definicja MŚP. Poradnik dla użytkowników i wzór oświadczenia, „Przedsiębiorstwo i Przemysł", www.parp.gov.p1/files/74/87/1155.pdf [dostęp: 10.03.2018]. 
może przekroczyć równowartości 200 tys. euro brutto (a w przypadku podmiotu prowadzącego działalność gospodarczą w sektorze transportu drogowego - 100 tys. euro brutto) w okresie 3 kolejnych lat podatkowych ${ }^{31}$. Wysokość wsparcia jest ustalana i podawana $\mathrm{w}$ euro $\mathrm{w}$ kwocie brutto, $\mathrm{tj}$. nie uwzględnia się potrąceń $\mathrm{z}$ tytułu podatków i innych opłat. Równowartość pomocy w euro ustala się według kursu średniego walut obcych, ogłaszanego przez Narodowy Bank Polski, obowiązującego w dniu udzielenia pomocy (art. 11 ust. 3 ustawy o postępowaniu w sprawach dotyczących pomocy publicznej; także wyrok Wojewódzkiego Sądu Administracyjnego w Opolu z dnia 10 listopada 2009 r. $^{32}$ ). Przy czym pomoc uznaje się za przyznaną $\mathrm{w}$ dniu, w którym przedsiębiorca nabywa prawo otrzymania takiej pomocy zgodnie z obowiązującym krajowym systemem prawnym, niezależnie od terminu wypłacenia pomocy (art. 3 ust. 2 rozporządzenia Komisji nr 1407/2013). $\mathrm{W}$ polskim porządku prawnym termin ten jest tożsamy z datą zawarcia umowy lub wydania decyzji administracyjnej, na podstawie której przyznano pomoc ${ }^{33}$.

Wskazane pułapy finansowe stosuje się bez względu na formę i cel pomocy de minimis. Znaczenia nie ma również fakt, czy jest ona w całości czy w części finansowana ze środków unijnych. Okres 3 lat należy oceniać w sposób ciągły, zatem dla każdego przypadku nowej pomocy de minimis należy uwzględnić całkowitą kwotę pomocy de minimis przyznaną w ciągu danego roku podatkowego oraz dwóch poprzedzających lat podatkowych ${ }^{34}$. W oparciu o powyższe można rzec, że pomoc bagatelna kumuluje się z:

- każdą pomocą udzieloną w ciągu trzech kolejnych lat, którą uzyskał przedsiębiorca poza jakimkolwiek programem pomocowym notyfikowanym przez Komisję Europejską, do łącznej kwoty wsparcia ${ }^{35}$,

- każdą inną pomocą de minimis bez względu na jej źródło (krajowe, regionalne, europejskie), formę oraz przeznaczenie (inwestycje, doradztwo itp. ${ }^{36}$.

Cechą charakterystyczną pomocy bagatelnej jest brak określenia celu, na jaki ma być przeznaczona ${ }^{37}$. Co do zasady, pomoc, o której mowa, jest wykorzystywana na pokrycie wydatków bezpośrednio związanych z rozwojem działalności gospo-

${ }^{31}$ K. Gałązka, Pomoc publiczna dla przedsiębiorców, Warszawa 2012, s. 33.

32 I SA/Op 270/09, LEX nr 531634.

33 Zgodnie z wyrokiem WSA w Rzeszowie z dnia 3 października 2017 r. (I SA/Rz 497/17, LEX nr 2376320) obliczenie i ustalenie, czy przyznana pomoc przekracza wskazaną kwotę, winno następować na dzień, kiedy przedsiębiorstwo uzyskuje prawo otrzymania takiej pomocy.

${ }^{34}$ Pomoc publiczna i pomoc de minimis w praktyce. Podręcznik beneficjentów Regionalnego Programu Operacyjnego Województwa Mazowieckiego 2007-2013, Warszawa 2010, s. 31.

${ }_{35}$ Pomoc publiczna. Poradnik przedsiębiorcy, red. A. Tokaj-Krzewska, A. Żołnierski, Warszawa 2003, s. 7.

36 A. Jankowska, op. cit., s. 74.

37 I. Postuła, A. Werner, Pomoc publiczna, Warszawa 2006, s. 150. 
darczej (np. dofinansowanie projektów w przedmiocie rozwoju technologicznego ${ }^{38}$ ) czy zwiększeniem zatrudnienia przedsiębiorstwa (np. utworzenie nowych miejsc pracy związanych z nową inwestycją ${ }^{39}$ ). Pomoc de minimis może być udzielona także w celu ułatwienia sfinansowania pierwszych wydatków inwestycyjnych związanych z prowadzoną działalnością gospodarczą. Często służy ona do zapewnienia specjalistycznych usług doradczo-szkoleniowych umożliwiających podnoszenie kwalifikacji zawodowych i nabywanie umiejętności niezbędnych do prowadzenia działalności gospodarczej (np. pod postacią dofinansowania kształcenia młodocianego pracownika ${ }^{40}$ ).

W myśl przyjętych zasad pomoc de minimis przeznacza się na rozwój przedsiębiorstwa. Jej celem nie jest restrukturyzacja przedsiębiorcy znajdującego się w trudnej sytuacji finansowej. Zgodnie z Wytycznymi Komisji Europejskiej, dotyczącymi pomocy państwa na ratowanie i restrukturyzację przedsiębiorstw niefinansowych znajdujących się w trudnej sytuacji ${ }^{41}$, za ,przedsiębiorstwo znajdujące się w trudnej sytuacji" uznaje się takie przedsiębiorstwo, co do którego można przyjąć, iż bez interwencji państwa prawie na pewno będzie skazane na zniknięcie z rynku w perspektywie krótkoterminowej lub średnioterminowej. Fakt, że przedsiębiorca znajduje się w złej kondycji ekonomicznej (np. znajduje się w stanie likwidacji ${ }^{42}$ ), jest jednym z czynników wykluczających możliwość skorzystania ze wsparcia ${ }^{43}$. Co szczególnie istotne, w Wytycznych Komisji Europejskiej przyjmuje się też, że nowo utworzone przedsiębiorstwo nie kwalifikuje się do uzyskania pomocy nawet wtedy, jeśli jego początkowa sytuacja finansowa jest niepewna. Dotyczy to przykładowo sytuacji, gdy nowo utworzone przedsiębiorstwo powstaje w wyniku likwidacji poprzedniego przedsiębiorstwa lub jedynie przejmuje jego aktywa.

W myśl art. 1 rozporządzenia Komisji nr 1407/2013 o wsparcie de minimis nie mogą ubiegać się przedsiębiorcy działający w sektorach:

- rybołówstwa i akwakultury ${ }^{44}$,

- produkcji podstawowej produktów rolnych ${ }^{45}$,

38 Wyrok WSA w Kielcach z dnia 26 października 2016 r., I SA/Ke 519/16, LEX nr 2150713.

39 Wyrok WSA we Wrocławiu z dnia 30 stycznia 2018 r., I SA/Wr 1114/17, LEX nr 2446341.

${ }^{40}$ Wyrok WSA w Kielcach z dnia 19 marca 2015 r., II SA/Ke 144/15, LEX nr 1812600.

${ }^{41}$ Komunikat Komisji Europejskiej „Wytyczne dotyczące pomocy państwa na ratowanie i restrukturyzację przedsiębiorstw niefinansowych znajdujących się w trudnej sytuacji” (Dz.Urz. UE C 249, 31.07.2014).

${ }_{42}$ Wyrok WSA w Szczecinie z dnia 9 marca 2011 r., I SA/Sz 703/10, LEX nr 991450.

${ }^{43}$ Pomoc publiczna w Programach Operacyjnych..., s. 39.

${ }^{44} \mathrm{~W}$ tym obszarze obowiązuje rozporządzenie Komisji (UE) nr 717/2014 z dnia 27 czerwca 2014 r. w sprawie stosowania art. 107 i 108 Traktatu o funkcjonowaniu Unii Europejskiej do pomocy de minimis w sektorze rybołówstwa i akwakultury (Dz.Urz. UE L 190/45, 28.06.2014).

${ }^{45}$ W tym obszarze obowiązuje rozporządzenie Komisji (UE) nr 1408/2013 z dnia 18 grudnia 2013 r. w sprawie stosowania art. 107 i 108 Traktatu o funkcjonowaniu Unii Europejskiej do pomocy de minimis w sektorze rolnym (Dz.Urz. UE L 352/9, 24.12.2013). 
- przetwarzania i wprowadzania do obrotu produktów rolnych w następujących przypadkach: kiedy wysokość pomocy ustalana jest na podstawie ceny lub ilości takich produktów nabytych od producentów podstawowych lub wprowadzonych na rynek przez przedsiębiorstwa objęte pomocą oraz kiedy przyznanie pomocy zależy od faktu przekazania jej w części lub w całości producentom podstawowym,

- działalności związanej z wywozem do państw trzecich lub państw członkowskich,

- pomocy uwarunkowanej pierwszeństwem korzystania z towarów krajowych w stosunku do towarów sprowadzanych z zagranicy.

Omawiając problematykę pomocy bagatelnej, należy mieć na uwadze jeszcze inne ograniczenia. Zgodnie z nimi w ramach jednego projektu pomoc de minimis nie może być kumulowana z innymi sposobami pomocy, jeśli powodowałoby to przekroczenie dopuszczalnej jej intensywności. Pomoc de minimis nie może być udzielana łącznie z pomocą publiczną udzielaną na podstawie wyłączeń grupowych lub na podstawie programów pomocowych (w zakresie tych samych kosztów kwalifikowanych) w sytuacji, gdyby kumulacja doprowadziła do podniesienia poziomu intensywności pomocy ponad maksymalny dopuszczalny próg finansowy ${ }^{46}$. Dodatkowe obostrzenie zakłada, że omawiane wsparcie nie może być przekazywane w ramach tzw. form nieprzejrzystych, czyli takich, w stosunku do których konieczne byłoby przeprowadzenie oceny ryzyka dla obliczenia wartości pomocy (art. 4 rozporządzenia Komisji nr 1407/2013 $)^{47}$. Przy czym za przejrzystą pomoc de minimis uznaje się pomoc $\mathrm{w}$ formie dotacji lub dopłat do oprocentowania. Natomiast pomoc w formie pożyczek, dokapitalizowania, gwarancji, środków finansowania ryzyka przyjmujących postać inwestycji kapitałowych i quasi-kapitałowych, a także innych instrumentów uważa się za przejrzystą po spełnieniu przesłanek wskazanych w treści rozporządzenia Komisji nr 1407/2013 ${ }^{48}$.

Pomoc de minimis nie może być też skierowana do beneficjenta w przypadku, gdy ten nieprawidłowo sporządzi wniosek bądź nie przedstawi zaświadczeń o uzyskanej dotychczas pomocy de minimis.

46 A. Jankowska, M. Marek, op. cit., s. 115.

${ }^{47}$ Regułą jest, że pomoc de minimis może być udzielana jedynie w formach przejrzystych, tj. takich, w odniesieniu do których możliwe jest ex ante dokładne obliczenie ich ekwiwalentu dotacji brutto, bez potrzeby przeprowadzania oceny ryzyka (art. 4 rozporządzenia Komisji nr 1407/2013).

48 Przykładowo, w myśl rozporządzenia Komisji nr 1407/2013, pomoc w formie pożyczek, w tym pomoc de minimis na finansowanie ryzyka przyjmująca postać pożyczek, należy uznać za przejrzystą pomoc de minimis, jeżeli ekwiwalent dotacji brutto został obliczony na podstawie rynkowych stóp procentowych obowiązujących w chwili przyznania pomocy, natomiast pomocy w formie dokapitalizowania nie należy uznawać za przejrzystą pomoc de minimis, chyba że całkowita wartość dokapitalizowania ze środków publicznych nie przekracza pułapu de minimis. 


\section{PROCEDURA UDZIELENIA POMOCY BAGATELNEJ}

Warunkiem przyznania pomocy de minimis jest właściwe złożenie wniosku, który podlega ocenie formalnej i merytorycznej, przeprowadzanej przez niezależnych ekspertów specjalizujących się w dziedzinie będącej przedmiotem oceny. Zgodnie z $§ 2$ rozporządzenia Rady Ministrów z dnia 29 marca 2010 r. w sprawie zakresu informacji przedstawianych przez podmiot ubiegający się o pomoc de minimis, wnioskodawca przedstawia podmiotowi udzielającemu pomocy szereg informacji dotyczących jego osoby. Chodzi tu o takie informacje, jak:

- imię i nazwisko albo nazwa,

- adres miejsca zamieszkania albo adres siedziby,

- identyfikator gminy, w której wnioskodawca ma miejsce zamieszkania albo siedzibę,

- numer identyfikacji podatkowej (NIP),

- forma prawna,

- wielkość,

- klasa działalności, w związku z którą wnioskodawca ubiega się o pomoc de minimis, zgodnie z rozporządzeniem Rady Ministrów z dnia 24 grudnia 2007 r. w sprawie Polskiej Klasyfikacji Działalności (PKD) ${ }^{49}$,

- data utworzenia,

- wskazanie powiązań z innymi przedsiębiorcami,

- informacje o utworzeniu wnioskodawcy w wyniku podziału innego przedsiębiorcy lub połączenia $\mathrm{z}$ innym przedsiębiorcą, $\mathrm{w}$ tym przez przejęcie innego przedsiębiorcy.

Wnioskodawca przekazuje również informacje dotyczące jego sytuacji ekonomicznej i prowadzonej działalności gospodarczej ${ }^{50}$. Niezbędne z jego strony jest ujawnienie szczegółów dotyczących pomocy otrzymanej w odniesieniu do tych samych kosztów kwalifikujących się do objęcia pomocą, na pokrycie których ma być przeznaczona pomoc de minimis, a także szczegółowych informacji w przedmiocie rekompensaty otrzymanej z tytułu wykonywania usługi świadczonej w ogólnym interesie gospodarczym w odniesieniu do tej samej usługi, w związku z którą wnioskodawca ubiega się o pomoc de minimis.

Zgodnie z wyrokiem WSA w Warszawie z dnia 25 czerwca 2015 r. „,koniecznym warunkiem do uzyskania pomocy de minimis jest złożenie przez podmiot ubiegający się o taką pomoc, dokumentów, o jakich mowa w art. 37 ust. 1 ustawy z 2004 r.

49 Dz.U. z 2007 r., nr 251, poz. 1885.

50 ,Ewentualna poprawa sytuacji ekonomicznej wnioskodawcy po dniu złożenia wniosku nie ma znaczenia dla przyznania pomocy". Zob. wyrok WSA w Warszawie z dnia 7 lutego 2017 r., V SA/Wa 181/16, LEX nr 2305726; wyrok WSA w Warszawie z dnia 4 kwietnia 2017 r., V SA/Wa 1501/16, LEX nr 2323558. 
o postępowaniu w sprawach dotyczących pomocy publicznej”51. Chodzi tu o powinność podmiotu dotyczącą przekazania wraz z wnioskiem o udzielenie pomocy:

1) wszystkich zaświadczeń o pomocy de minimis, jakie otrzymał w roku, w którym ubiega się o pomoc, oraz w ciągu 2 poprzedzających go lat, albo oświadczenia o wielkości pomocy de minimis otrzymanej w tym okresie, albo oświadczenia o nieotrzymaniu takiej pomocy w tym okresie,

2) informacji niezbędnych do udzielenia pomocy de minimis, dotyczących w szczególności wnioskodawcy i prowadzonej przez niego działalności gospodarczej oraz wielkości i przeznaczenia pomocy publicznej otrzymanej w odniesieniu do tych samych kosztów kwalifikujących się do objęcia pomocą, na pokrycie których ma być przeznaczona pomoc de minimis ${ }^{52}$.

Zaświadczenia stwierdzające, że pomoc publiczna jest pomocą de minimis (pkt 1), zobowiązane są wystawiać z urzędu podmioty udzielające pomocy ${ }^{53}$. O powinności tej stanowi art. 5 ust. 3 ustawy 30 kwietnia 2004 r. o postępowaniu w sprawach dotyczących pomocy publicznej. Przepis ten nakłada na wskazane podmioty obowiązek określonego działania polegającego na podejmowaniu czynności materialno-technicznych, sprowadzających się do wydawania zaświadczeń, w których następuje urzędowe potwierdzenie stanu faktycznego lub prawnego ${ }^{54}$. Formę i treść zaświadczeń oraz terminy lub sposób ich wydawania określa Rada Ministrów w drodze rozporządzenia. Obecnie tematyka zaświadczeń jest regulowana przez rozporządzenie Rady Ministrów z dnia 20 marca 2007 r. w sprawie zaświadczeń o pomocy de minimis i pomocy de minimis w rolnictwie lub rybołówstwie ${ }^{55}$.

Do czasu przekazania przez podmiot ubiegający się o pomoc zaświadczeń, oświadczeń lub informacji o otrzymanej dotychczas pomocy publicznej, wnioskodawcy nie może zostać udzielona pomoc. Nieprzedłożenie wymaganych dokumentów wywołuje doniosły skutek w postaci odmowy przyznania pomocy de minimis ${ }^{56}$.

Podkreślenia wymaga, że to na przedsiębiorcy ciąży obowiązek gromadzenia wszelkich dokumentów dotyczących uzyskanej pomocy i samodzielnego monitorowania, czy dostępny limit finansowy nie został przekroczony. Niedochowanie należytej staranności w tym zakresie może się wiązać z przekroczeniem dopusz-

51 VIII SA/Wa 90/15, LEX nr 1777380.

${ }^{52}$ Pomoc publiczna i pomoc de minimis $w$ praktyce..., s. 31.

${ }^{53}$ K. Kwapisz-Krygel, Postepowanie w sprawach dotyczacych pomocy publicznej. Komentarz, Warszawa 2015, s. 29.

${ }^{54}$ Wyrok WSA w Łodzi z dnia 12 października 2010 r., I SA/Ld 810/10, LEX nr 612160.

55 Zob. także: wyrok WSA w Bydgoszczy z dnia 30 czerwca 2010 r., I SA/Bd 50/10, LEX nr 590326; wyrok WSA w Warszawie z dnia 25 czerwca 2015 r., VIII SA/Wa 110/15, LEX nr 1777371.

56 „Uzupełnienie dokumentacji na wezwanie organu kontrolującego nie może konwalidować błędu polegającego na nieuzyskaniu tych informacji przed udzieleniem pomocy publicznej”. Zob. wyrok WSA w Warszawie z dnia 23 października 2012 r., V SA/Wa 1615/12, LEX nr 1343748. 
czalnego progu finansowego, a co za tym idzie z koniecznością zwrotu nienależnie przyznanej pomocy ${ }^{57}$.

Państwo członkowskie udzielające pomocy de minimis zobowiązane jest pisemnie powiadomić podmiot ubiegający się o wsparcie o przewidywanej kwocie pomocy oraz poinformować, iż pomoc ta stanowi pomoc de minimis (art. 6 ust. 1 rozporządzenia Komisji nr 1407/2013). Innym obowiązkiem państw członkowskich jest rejestrowanie i gromadzenie wszelkich informacji dotyczących udzielonego wsparcia, przy czym:

- dane dotyczące indywidualnej pomocy de minimis przechowuje się przez 10 lat podatkowych od daty przyznania pomocy,

- dane dotyczące programu pomocy de minimis przechowuje się przez 10 lat podatkowych od daty przyznania ostatniej indywidualnej pomocy w ramach takiego programu (art. 6 ust. 4 rozporządzenia Komisji nr 1407/2013).

Na państwie członkowskim ciąży też powinność przedkładania - na pisemny wniosek Komisji Europejskiej - w ciągu 20 dni roboczych lub w ciągu dłuższego okresu określonego we wniosku wszystkich informacji, jakie Komisja Europejska uzna za niezbędne do oceny, czy zostały spełnione warunki udzielonej pomocy, a w szczególności czy nie zostały przekroczone całkowite kwoty pomocy de minimis otrzymanej przez przedsiębiorstwo (art. 6 ust. 5 rozporządzenia Komisji nr 1407/2013).

Organem nadzorującym przyznawanie pomocy publicznej i monitorującym jej przebieg jest Prezes Urzędu Ochrony Konkurencji i Konsumentów, który - jako centralny organ administracji państwowej - przedstawia Komisji, na jej wniosek, informacje o pomocy de minimis (art. 37 ust. 3 ustawy o postępowaniu w sprawach dotyczących pomocy publicznej). W ramach swoich uprawnień kontrolnych Prezes wydaje opinie co do zgodności projektów programów pomocowych z obecnie obowiązującymi przepisami prawa ${ }^{58}$. Opiniowaniu poddane są takie formy pomocy, jak: dotacje, pożyczki, kredyty preferencyjne, dopłaty do oprocentowania kredytów bankowych, poręczenia, gwarancje, umorzenie zaległości podatkowej, odroczenie płatności należności publicznoprawnych, rozłożenie na raty płatności należności publicznoprawnych. Proces monitorowania pomocy de minimis polega zaś na gromadzeniu przesyłanych sprawozdań o udzielonej pomocy w centralnej, na bieżąco aktualizowanej bazie danych o udzielonej pomocy de minimis, której rolę pełni aktualnie aplikacja SHRIMP ${ }^{59}$. Baza ta stanowi centralny rejestr wsparcia bagatelnego i umożliwia podmiotom udzielającym pomocy de minimis

${ }_{57}$ M. Wietrzny, Zmiany $w$ zasadach udzielania pomocy de minimis, www.pwc.pl/pl/artykuly/2014/zmiany-w-zasadach-udzielania-pomocy-de-minimis.html [dostęp: 09.03.2018].

${ }_{58}$ Pomoc publiczna. Poradnik przedsiębiorcy..., s. 7.

59 Sporządzanie sprawozdań z wykorzystaniem aplikacji SHRIMP, www.uokik.gov.pl/sporzadzanie_sprawozdan_z_wykorzystaniem_aplikacji_shrimp.php [dostęp: 09.03.2018]. 
weryfikowanie bezpośrednio przed udzieleniem tej pomocy (na zasadzie dostępu online) wielkości pomocy otrzymanej przez danego beneficjenta, a w konsekwencji możliwości udzielenia mu kolejnej pomocy przy uwzględnieniu obowiązującego limitu $^{60}$. Ponadto rola Prezesa w zakresie udzielania pomocy de minimis sprowadza się do zapewnienia zgodności projektów programów tej pomocy z przepisami rozporządzenia Komisji nr 1407/2013 oraz rozporządzenia Komisji (UE) nr 360/2012 ${ }^{61}$ i obejmuje m.in.:

- aktywne uczestnictwo w procesie legislacyjnym w odniesieniu do aktów prawnych będących podstawami prawnymi udzielania pomocy de minimis,

- zgłaszanie w terminie 14 dni zastrzeżeń do projektów programów pomocy de minimis w zakresie przejrzystości planowanej pomocy,

- zgłaszanie organom udzielającym pomocy de minimis informacji o zidentyfikowanych nieprawidłowościach w jej udzielaniu oraz sprawozdawaniu ${ }^{62}$.

\section{PODSUMOWANIE}

W obecnym porządku prawnym istnieje stosunkowa łatwość udzielania pomocy de minimis i elastyczność stosowania jej w praktyce. Znaczna grupa mikro, małych i średnich przedsiębiorców korzysta ze sposobności uzyskania pomocy bagatelnej na pokrycie pierwszych wydatków inwestycyjnych związanych z prowadzoną działalnością gospodarczą. Wsparcie ze strony państwa w realny sposób przyczynia się do poprawy kondycji gospodarczej przedsiębiorców oraz tworzenia nowych miejsc pracy. Podkreślenia jednak wymaga, że - ze względu na niewielkie rozmiary - nie do końca pozwala ono na sfinansowanie całości inwestycji. Co do zasady, pomoc de minimis jest wykorzystywana jako uzupełniające źródło finansowania projektów. Głównym sposobem pozyskiwania środków pieniężnych jest natomiast ubieganie się o przyznanie innego rodzaju pomocy publicznej (np. regionalnej pomocy inwestycyjnej).

Konkretne dane liczbowe w przedmiocie liczby podmiotów korzystających $\mathrm{z}$ analizowanej formy pomocy przedstawiają raporty Urzędu Ochrony Konkurencji i Konsumentów o pomocy de minimis. W związku z brakiem wpływu na handel wewnątrzunijny pomoc bagatelna nie jest szczegółowo omawiana w sporządzanym corocznie przez Prezesa UOKiK raporcie o pomocy publicznej. Jednak ze względu

${ }^{60}$ Raport o pomocy de minimis $w$ Polsce udzielonej przedsiębiorcom $w 2016$ roku, UOKiK, Warszawa 2016, www.uokik.gov.pl/raporty_i_analizy2.php [dostęp: 08.03.2018].

${ }^{61}$ Rozporządzenie Komisji (UE) nr 360/2012 z dnia 25 kwietnia 2012 r. w sprawie stosowania art. 107 i 108 Traktatu o funkcjonowaniu Unii Europejskiej do pomocy de minimis przyznawanej przedsiębiorstwom wykonującym usługi świadczone w ogólnym interesie gospodarczym (Dz.Urz. UE L 114/8 26.04.2012).

${ }^{62}$ Raport o pomocy de minimis $w$ Polsce... 
na fakt, że co roku łączna wartość pomocy de minimis jest relatywnie duża, Prezes UOKiK od 2008 r. przygotowuje odrębny raport dotyczący tej pomocy. Na podstawie raportu o pomocy de minimis w Polsce udzielonej przedsiębiorcom w $2016 \mathrm{r}$. można wysnuć kilka wniosków:

- w latach 2012-2014 obserwowany był wzrost ogólnej wartości pomocy de minimis, a w 2014 r. osiągnęła ona najwyższą dotychczas wartość - 6 629,6 $\mathrm{mln} \mathrm{zł}$,

- w latach 2012-2014 tendencja wzrostowa wartości pomocy de minimis była związana przede wszystkim ze wzrostem pomocy udzielanej na podstawie ustawy z dnia 20 kwietnia 2004 r. o promocji zatrudnienia i instytucjach rynku pracy ${ }^{63}$ czy ustawy z dnia 7 września 1991 r. o systemie oświaty ${ }^{64}$ (na dofinansowanie kosztów kształcenia młodocianych pracowników),

- w 2015 r. odnotowano spadek wartości udzielonej pomocy o około 1/4 $\mathrm{w}$ porównaniu z rokiem poprzednim. Wynikał on głównie ze zmniejszenia wartości pomocy udzielanej w ramach ustawy z dnia 6 grudnia 2006 r. o zasadach prowadzenia polityki rozwoju ${ }^{65}$, ustawy z dnia 9 listopada $2000 \mathrm{r}$. o utworzeniu Polskiej Agencji Rozwoju Przedsiębiorczości ${ }^{66}$ oraz ustawy z dnia 7 marca 2007 r. o wspieraniu rozwoju obszarów wiejskich z udziałem środków Europejskiego Funduszu Rolnego na rzecz Rozwoju Obszarów Wiejskich w ramach Programu Rozwoju Obszarów Wiejskich na lata 2007-2013 ${ }^{67}$. Spadek ten stanowił konsekwencję zakończenia projektów realizowanych w ramach programów unijnych perspektywy finansowej 2007-2013,

- w 2016 r. nastąpił wzrost udzielonej pomocy o około 10\% w stosunku do roku poprzedniego (wartość pomocy wyniosła $5363,7 \mathrm{mln}$ zł).

W latach 2012-2016 wśród form pomocy de minimis dominowały głównie dotacje, ulgi podatkowe i refundacje. Drugiej co do wielkości pomocy udzielano $\mathrm{w}$ formie poręczeń i gwarancji. Trzecie miejsce zajęły kredyty preferencyjne i pożyczki. Najmniejszą popularnością wśród przedsiębiorców cieszyły się subsydia kapitałowo-inwestycyjne. W 2016 r.:

- około 3,3 tys. podmiotów, mających prawo do udzielania pomocy publicznej, udzieliło przedsiębiorcom pomocy de minimis,

- grupą podmiotów, która w sumie udzieliła pomocy o największej wartości, były organy jednostek samorządu terytorialnego - 66,7\% łącznej wartości

\footnotetext{
63 T.j. Dz.U. z 2017 r., poz. 1065.

64 T.j. Dz.U. z 2017 r., poz. 2198.

${ }_{65}$ T.j. Dz.U. z 2017 r., poz. 1376.

${ }_{66}^{6}$ T.j. Dz.U. z 2018 r., poz. 110.

${ }^{67}$ T.j. Dz.U. z 2017 r., poz. 1856.
} 
pomocy (w ramach tej grupy najwięcej pomocy udzielili starostowie powiatów),

- najwięcej pomocy uzyskali przedsiębiorcy prywatni (aż około 96\% ogólnej wartości pomocy),

- prawie 96\% pomocy de minimis udzielono mikro, małym i średnim przedsiębiorcom.

Największy wzrost wartości pomocy de minimis udzielonej w 2016 r. w stosunku do roku poprzedniego wystąpił w przypadku mikroprzedsiębiorców oraz małych przedsiębiorców. Średni przedsiębiorcy otrzymali o $25,2 \mathrm{mln}$ zł, czyli o około 5\%, więcej pomocy de minimis. Jedyną grupą, w której odnotowano spadek udzielonej pomocy, są duzi przedsiębiorcy - o $16 \%$.

Jak wykazują powyżej zaprezentowane dane liczbowe, mniejsze podmioty, szczególnie te wkraczające na rynek i rozpoczynające działalność gospodarczą, corocznie wykazują nadzwyczajnie wysokie zainteresowanie uzyskaniem pomocy de minimis. W dużej mierze wynika to z prostych zasad jej stosowania, przejrzystej procedury udzielania oraz braku konieczności powiązania wsparcia z konkretnym projektem czy przedsięwzięciem. Potwierdzeniem tej tezy jest fakt, że wśród beneficjentów pomocy bagatelnej nadal dominują mikro, mali i średni przedsiębiorcy, którzy mają aż 96-procentowy udział w ogólnej wartości przekazanej pomocy de minimis.

\section{BIBLIOGRAFIA}

Borkowski A., Pomoc publiczna jako funkcja państwa wobec społecznej gospodarki rynkowej, „Przegląd Prawa i Administracji” 2015, nr 103.

Choroszczak J., Mikulec M., Pomoc publiczna a rozwój firmy. Szanse i zagrożenia, Warszawa 2012.

Fornalczyk A., Rodzaje, formy i instrumenty pomocy publicznej w Unii Europejskiej $i$ w Polsce, [w:] Pomoc publiczna dla przedsiębiorstw w Unii Europejskiej i w Polsce, red. A. Fornalczyk, Warszawa 1998.

Gałązka K., Pomoc publiczna dla przedsiębiorców, Warszawa 2012.

Jankowska A., Pomoc publiczna dla przedsiębiorców w świetle uregulowań wspólnotowych. Zasady i ograniczenia udzielania, Warszawa 2005.

Jankowska A., Marek M., Dopuszczalność pomocy publicznej. Uregulowania wspólne i krajowe, Warszawa 2009.

Komunikat Komisji Europejskiej „Wytyczne dotyczące pomocy państwa na ratowanie i restrukturyzację przedsiębiorstw niefinansowych znajdujących się w trudnej sytuacji” (Dz.Urz. UE C 249, 31.07.2014).

Kwapisz-Krygel K., Postępowanie w sprawach dotyczacych pomocy publicznej. Komentarz, Warszawa 2015.

Marquardt P., Pomoc publiczna dla matych i średnich przedsiębiorców, Warszawa 2007.

Misiąg F., Charakterystyka sektora MSP, [w:] Pomoc publiczna dla matych i średnich przedsiębiorstw. Mity i rzeczywistośćc, red. F. Misiąg, Warszawa 2005.

Nowa definicja MŚP. Poradnik dla użytkowników i wzór oświadczenia, „Przedsiębiorstwo i Przemysł”, www.parp.gov.pl/files/74/87/1155.pdf [dostęp: 10.03.2018]. 
Pełka P., Stasiak M., Pomoc publiczna dla przedsiębiorców w Unii Europejskiej, Warszawa 2002. Pomoc publiczna i pomoc de minimis w praktyce. Podręcznik beneficjentów Regionalnego Programu Operacyjnego Województwa Mazowieckiego 2007-2013, Warszawa 2010.

Pomoc publiczna. Poradnik przedsiębiorcy, red. A. Tokaj-Krzewska, A. Żołnierski, Warszawa 2003. Pomoc publiczna w Programach Operacyjnych 2007-2013. Poradnik dla administracji publicznej wraz z komentarzami do rozporządzeń Ministra Rozwoju Regionalnego, Ministerstwo Rozwoju Regionalnego, marzec 2008.

Postuła I., Werner A., Pomoc publiczna, Warszawa 2006.

Raport o pomocy de minimis $w$ Polsce udzielonej przedsiębiorcom w 2016 roku, UOKiK, Warszawa 2016, www.uokik.gov.pl/raporty_i_analizy2.php [dostęp: 08.03.2018].

Rozporządzenie Komisji (UE) nr 360/2012 z dnia 25 kwietnia 2012 r. w sprawie stosowania art. 107 i 108 Traktatu o funkcjonowaniu Unii Europejskiej do pomocy de minimis przyznawanej przedsiębiorstwom wykonującym usługi świadczone w ogólnym interesie gospodarczym (Dz.Urz. UE L 114/8 26.04.2012).

Rozporządzenie Komisji (UE) nr 1407/2013 z dnia 18 grudnia 2013 r. w sprawie stosowania art. 107 i 108 Traktatu o funkcjonowaniu Unii Europejskiej do pomocy de minimis (Dz.Urz. UE L 352, 24.12.2013).

Rozporządzenie Komisji (UE) nr 1408/2013 z dnia 18 grudnia 2013 r. w sprawie stosowania art. 107 i 108 Traktatu o funkcjonowaniu Unii Europejskiej do pomocy de minimis w sektorze rolnym (Dz.Urz. UE L 352/9, 24.12.2013).

Rozporządzenie Komisji (UE) nr 717/2014 z dnia 27 czerwca 2014 r. w sprawie stosowania art. 107 i 108 Traktatu o funkcjonowaniu Unii Europejskiej do pomocy de minimis w sektorze rybołówstwa i akwakultury (Dz.Urz. UE L 190/45, 28.06.2014).

Rozporządzenie Rady Ministrów z dnia 20 marca 2007 r. w sprawie zaświadczeń o pomocy de minimis i pomocy de minimis w rolnictwie lub rybołówstwie (t.j. Dz.U. z 2018 r., poz. 350).

Rozporządzenie Rady Ministrów z dnia 24 grudnia 2007 r. w sprawie Polskiej Klasyfikacji Działalności (PKD) (Dz.U. z 2007 r., nr 251, poz. 1885).

Rozporządzenie Rady Ministrów z dnia 29 marca 2010 r. w sprawie zakresu informacji przedstawianych przez podmiot ubiegający się o pomoc de minimis (Dz.U. z 2010 r., nr 53, poz. 311).

Sporządzanie sprawozdań z wykorzystaniem aplikacji SHRIMP, www.uokik.gov.pl/sporzadzanie_sprawozdan_z_wykorzystaniem_aplikacji_shrimp.php [dostęp: 09.03.2018].

Strużycki M., Specyfika działalności rynkowej małych i średnich przedsiębiorstw, [w:] Zarządzanie małym i średnim przedsiębiorstwem, red. M. Strużycki, Warszawa 2002.

Szóstakowska J., Pomoc publiczna, http://uniaeuropejska.org/pomoc-publiczna [dostęp: 08.03.2018].

Traktat o Unii Europejskiej i Traktat o funkcjonowaniu Unii Europejskiej, wersja skonsolidowana (Dz.Urz. UE C 202, 07.06.2016).

Układ Europejski ustanawiający stowarzyszenie między Rzecząpospolitą Polską, z jednej strony, a Wspólnotami Europejskimi i ich państwami członkowskimi, z drugiej strony, sporządzony w Brukseli dnia 16 grudnia 1991 r. (Dz.U. z 1994 r., nr 11, poz. 38).

Ustawa z dnia 7 września 1991 r. o systemie oświaty (t.j. Dz.U. z 2017 r., poz. 2198).

Ustawa z dnia 9 listopada 2000 r. o utworzeniu Polskiej Agencji Rozwoju Przedsiębiorczości (t.j. Dz.U. z 2018 r., poz. 110).

Ustawa z dnia 20 kwietnia 2004 r. o promocji zatrudnienia i instytucjach rynku pracy (t.j. Dz.U. z 2017 r., poz. 1065).

Ustawa z dnia 30 kwietnia 2004 r. o postępowaniu w sprawach dotyczących pomocy publicznej (t.j. Dz.U. z 2018 r., poz. 362).

Ustawa z dnia 6 grudnia 2006 r. o zasadach prowadzenia polityki rozwoju (t.j. Dz.U. z 2017 r., poz. 1376).

Ustawa z dnia 7 marca 2007 r. o wspieraniu rozwoju obszarów wiejskich z udziałem środków Europejskiego Funduszu Rolnego na rzecz Rozwoju Obszarów Wiejskich w ramach Programu Rozwoju Obszarów Wiejskich na lata 2007-2013 (t.j. Dz.U. z 2017 r., poz. 1856). 
Ustawa z dnia 6 marca 2018 r. - Prawo przedsiębiorców (Dz.U. z 2018 r., poz. 646).

Wietrzny M., Zmiany w zasadach udzielania pomocy de minimis, www.pwc.pl/pl/artykuly/2014/ zmiany-w-zasadach-udzielania-pomocy-de-minimis.html [dostęp: 09.03.2018].

Wiktor J.W., Rynek Unii Europejskiej. Koncepcja i zasady funkcjonowania, Kraków 2005.

Wspólnotowe wytyczne w sprawie pomocy dla małych i średnich przedsiębiorców (Dz.Urz. UE C 213, 19.08.1992).

Wyrok TSUE z dnia 22 marca 1977 r. w sprawie C-78/76 Steinike \& Weinlig v. Germany, Zb. Orz. 1977, s. 595.

Wyrok TSUE z dnia 21 marca 1991 r. w sprawie C-303/88 Italian Republic v. Commission, Zb. Orz. 1991, s. I-1433.

Wyrok TSUE z dnia 26 września 1996 r. w sprawie C-241/94 France v. Commission, Zb. Orz. 1996, s. I-4551.

Wyrok TSUE z dnia 21 grudnia 2016 r. w sprawie C-76/15 Vervloet i in., pkt 102 (Dz.Urz. UE C 53, 20.02.2017).

Wyrok WSA w Opolu z dnia 10 listopada 2009 r., I SA/Op 270/09, LEX nr 531634.

Wyrok WSA w Bydgoszczy z dnia 30 czerwca 2010 r., I SA/Bd 50/10, LEX nr 590326.

Wyrok WSA w Łodzi z dnia 12 października 2010 r., I SA/Łd 810/10, LEX nr 612160.

Wyrok WSA w Szczecinie z dnia 9 marca 2011 r., I SA/Sz 703/10, LEX nr 991450.

Wyrok WSA w Warszawie z dnia 23 października 2012 r., V SA/Wa 1615/12, LEX nr 1343748.

Wyrok WSA w Kielcach z dnia 19 marca 2015 r., II SA/Ke 144/15, LEX nr 1812600.

Wyrok WSA w Warszawie z dnia 25 czerwca 2015 r., VIII SA/Wa 90/15, LEX nr 1777380.

Wyrok WSA w Warszawie z dnia 25 czerwca 2015 r., VIII SA/Wa 110/15, LEX nr 1777371.

Wyrok WSA w Kielcach z dnia 26 października 2016 r., I SA/Ke 519/16, LEX nr 2150713.

Wyrok WSA w Warszawie z dnia 7 lutego 2017 r., V SA/Wa 181/16, LEX nr 2305726.

Wyrok WSA w Warszawie z dnia 4 kwietnia 2017 r., V SA/Wa 1501/16, LEX nr 2323558.

Wyrok WSA w Rzeszowie z dnia 3 października 2017 r., I SA/Rz 497/17, LEX nr 2376320.

Wyrok WSA we Wrocławiu z dnia 30 stycznia 2018 r., I SA/Wr 1114/17, LEX nr 2446341.

Zalecenie Komisji Europejskiej 2003/361/WE z dnia 6 maja 2003 r. dotyczące definicji przedsiębiorstw mikro, małych i średnich (Dz.Urz. UE L 124, 20.05.2003).

\section{SUMMARY}

De minimis aid - as an aid of marginal size is characterized by its small amount and inability to affect competition on the internal market - can be granted to companies without notifying the European Commission. All issues related to its functionality are regulated by various legal acts both national and supranational. The main source of law regarding soft aid is regulation of the European Commission (EU) No. 1407/2013. Among Polish regulations, the crucial meaning is given to the Act of 30 April 2004 on proceedings in public aid cases and regulation of the Council of Ministers, supplementing and further developing the Act. In this article, the author analyses current regulations concerning soft aid. She presents rule for granting de minimis aid, a transparent procedure of awarding and monitoring. In the context of her reflections and provided data from the years 2012-2016, the author shows growth in power of the biggest beneficiaries of the soft aid, that is micro-, medium and small sized entrepreneurs, who are the driving force of economic development in Poland.

Keywords: public aid; soft aid; de minimis aid; microsized entrepreneur; small sized entrepreneur; medium sized entrepreneur; SME 